\title{
Integrated use of distillery spent wash and NP fertilizers on FH-142 cotton-a low cost practice
}

\author{
Waqar Hussain Shah ${ }^{1}$ and Mehrunisa Memon ${ }^{1 *}$ \\ 1. Department of Soil Science, Sindh Agriculture University, Tandojam-Pakistan \\ *Corresponding author's email: nisamemon@gmail.com \\ Citation \\ Waqar Hussain Shah and Mehrunisa Memon. Integrated use of distillery spent wash and NP fertilizers on FH-142 \\ cotton-a low cost practice. Pure and Applied Biology. Vol. 10, Issue 2, pp430-437.
}

http://dx.doi.org/10.19045/bspab.2021.100046

\begin{tabular}{llll}
\hline \hline Received: 06/07/2020 & Revised: 26/09/2020 & Accepted: 07/10/2020 & Online First: 20/10/2020 \\
\hline \hline
\end{tabular}

\section{Abstract}

Distillery spentwash, a sugar-industry discharge of plant origin generated during ethanol production can be used to fertilize the plants, instead of polluting the environment. A field experiment arranged in a split plot design consisted five spentwash spray concentrations $(0,5,10,15$ and $20 \%)$ as main split and four N-P rates i.e. $0,1 / 3^{\text {rd }}, 2 / 3^{\text {rd }}$ and full recommended $\left(0-0,46-23,93-46\right.$ and $140-70 \mathrm{~kg} \mathrm{~N}-\mathrm{P}_{2} \mathrm{O}_{5}$ $\mathrm{ha}^{-1}$ ) as sub-split, replicated thrice. Increasing the concentration of spentwash or N-P fertilizer rates alone and their interaction significantly increased growth, yield and leaf tissue NPK concentration. Yet, increasing the rates of N-P alone from $1 / 3^{\text {rd }}$ to full, did not increase the leaf tissue $\mathrm{K}$ concentration till foliar spray of spentwash. A full N-P fertilizer rate with $20 \%$ spentwash spray resulted in maximum plant height (130.77 cm), number of leaves (25.13), sympodia (20.12), squares (27.70), bolls (40.24) plant $^{-1}$, seed cotton yield $(4025 \mathrm{~kg}) \mathrm{ha}^{-1}$ and leaf tissue $\mathrm{N}(3.40 \%)$ and $\mathrm{P}(0.20 \%)$ without any adverse effects on soil or cotton plant. However, increasing the rate of N-P fertilizer from $2 / 3^{\text {rd }}$ to full or spentwash concentration from $15 \%$ to $20 \%$ did not influence the cotton attributes and yield. A $2 / 3^{\text {rd }} \mathrm{N}$ P rate with $20 \%$ spentwash spray increased seed cotton yield by $20 \%$, even over full N-P, which saved $1 / 3^{\text {rd }}$ cost of each N-P and complete $\mathrm{K}$, the best way to economize the chemical fertilizer inputs.

Keywords: Chemical fertilizer; Foliar spray; Leaf tissue; NPK substitution; Seed cotton yield

\section{Introduction}

Cultivation of cotton (Gossypium hirsutum L.) in Pakistan is mainly associated with the fiber used in textile industry. It contributes $4.5 \%$ to agriculture as a value addition and $0.8 \%$ to gross domestic product (GDP) of the country [1]. About $11 \%$ of the cultivable agricultural land is under cotton. However, the area under cotton has decreased from 2961 thousand hectares in 2014-15 to 2373 thousand hectares in 2018-19 [1], corresponding to a $20 \%$ decrease in the area and $12 \%$ in cotton production. The average seed cotton yield of the country is very low $\left(1990 \mathrm{~kg} \mathrm{ha}^{-1}\right)[1]$ in comparison to the yield by Australia (5416 kg ha $\left.{ }^{-1}\right)$, Turkey (5048 $\left.\mathrm{kg} \mathrm{ha}^{-1}\right)$, China (4748 $\left.\mathrm{kg} \mathrm{ha}^{-1}\right)$ and Mexico $\left(4675 \mathrm{~kg} \mathrm{ha}^{-1}\right)$ [2]. The low yields of cotton may be related to many problems like high or low population of plants, narrow row spacing, shortage of irrigation water, seed rate, variety, weed infestation, pest (sucking or bollworms), disease and yet the fertilizer management issues [3, 4]

Adequate supply of major nutrients increases the seed cotton yield and lint percentage [5]. Nitrogen is necessary throughout the growing season, its deficiency can reduce the vegetative and reproductive processes that leads to potential yield loss [6]. Phosphorus is necessary in cell division and stimulates the number of flowering buds and bolls. It effectively improves the growth, uptake of 
NPK, chlorophyll and dry matter content in cotton [7]. While K mainly improves fiber quality and is involved in different biochemical and physiological processes i.e. photosynthetic apparatus and root stimulus $[8,9]$. After the appearance of deficiency symptoms of K on cotton leaves, it is very difficult to achieve optimum cotton yield [10]. The cotton growers are generally applying ample quantities of $\mathrm{N}$, with some $\mathrm{P}$ and with no or very little $\mathrm{K}$. Therefore, application of major nutrients is not carried out as per crop requirement. According to [11], $150 \mathrm{~kg}$ of $\mathrm{K}$ in a hectare can give a cotton lint yield of $2500 \mathrm{~kg} \mathrm{ha}^{-1}$. This quantity of $\mathrm{K}$ fertilizer is almost equal to $\mathrm{N}$. The timely availability and cost related issues of chemical fertilizers with special reference to $K$ are the most common limitations for a cotton grower, hindering its application and ultimately the yield targets. Under present scenario, nutrient management of cotton, at low-cost practice is of primary importance and can have a huge impact on the growth and yield targets [8]. Therefore the alternate nutrient sources of plant origin must be included in the fertilizer management program.

In this connection, huge quantities of sugarindustry based distillery spentwash are generated locally after the production of ethanol. This liquid, a rich source of $\mathrm{K}$ (5000-7500 $\mathrm{mg} \mathrm{L}^{-1}$ ) some $\mathrm{N}$ (477-581 mg $\left.\mathrm{L}^{-1}\right), \mathrm{P}\left(55-210 \mathrm{mg} \mathrm{L}^{-1}\right)$ and other nutrients is disposed off in the vicinity of sugar mills and polluting the environment. The utilization of this liquid on agricultural crops can instead benefit the cotton grower by substituting part of the chemical fertilizer [12]. Application of spentwash in soil with or without dilution can increase the salt content of soil and may be harmful for the agricultural lands in the long run [13]. On the other side, foliar spray of spentwash after proper dilution with or without chemical fertilizers has been reported to be beneficial in vegetables i.e. tomato [14], legumes i.e. soybean [15] and fodder crops i.e. sorghum [16] as it is directly applied on the plant. The studies integrating chemical fertilizer with spentwash spray are scarce [14-16]. Yet, there are no studies on the use of local spentwash in the form of foliar spray either on cotton or other crops.

Keeping the farmers perspective of lowcost nutrient necessity in achieving sustainable yield targets, this study evaluated the effect of various concentrations of spentwash spray in conjunction with chemical fertilizer (N-P) rates in cotton.

\section{Materials and methods Cotton experiment}

The field experiment conducted (2018) at farmer's field, district Matiari, Sindh, Pakistan was a split plot design, with 20 treatments replicated thrice. The sub-plot size was $6 \mathrm{~m} \times 2.25 \mathrm{~m}$. The treatments consisted of five spentwash concentrations $(0,5,10,15$ and $20 \%)$ as main splits and four chemical (N-P) fertilizer rates i.e. 0-0 $(0), 46-23\left(1 / 3^{\text {rd }}\right), 93-46\left(2 / 3^{\text {rd }}\right)$ and $140-70$ $\mathrm{kg} \mathrm{N}-\mathrm{P}_{2} \mathrm{O}_{5} \mathrm{ha}^{-1}$ (full recommended) as subsplits, applied in the form of urea and diammonium phosphate (DAP). All the DAP and $1 / 4^{\text {th }}$ of the urea were applied at sowing time, and leftover urea in three splits during the crop growth. To ensure better crop growth, spentwash spray was carried out after 25 days of germination and continued at 15 days interval till maturity. Plastic sheet partitions were used to separate out the spray of different concentrations. All the agronomic practices, insect pest and disease control measures were taken as and when required. The crop was harvested at maturity. Plant height, number of leaves, sympodial branches, squares, bolls and seed cotton yield were recorded.

\section{Sampling and processing}

One liter polycarbonyl containers were sterilized prior to collection of spentwash from Matol Distillery Unit at Matiari Sugar Mills, district Matiari, Sindh-Pakistan. The samples were stored in ice boxes right away, transported to Soil Fertility Research Laboratory, Department of Soil Science, Sindh Agriculture University, Tandojam 
and refrigerated at $4^{\circ} \mathrm{C}$ [17]. Before its application, necessary dilutions $(0,5,10$, 15 , and $20 \%$ ) were prepared and analyzed for some spentwash characteristics. Prior to sowing of cotton, five soil samples were randomly collected at $0-15$ and $15-30 \mathrm{~cm}$ from the experimental field and composited depth-wise. After the removal of unwanted material, the samples were kept under shade for drying, brought to $2 \mathrm{~mm}$ particle size and preserved for the analysis of some soil properties. Composite main branch leaves ( ${ }^{\text {rd }}$ leaf from top) were collected, packed in paper envelops and brought to laboratory. The leaves were rinsed with tap water, followed by distilled water and dried first in shade, later in hot oven at $68^{\circ} \mathrm{C}$. The leaves were ground to fine powder and preserved for $\mathrm{N}, \mathrm{P}$ and $\mathrm{K}$ analyses.

\section{Analytical methods}

The spentwash samples were analyzed for $\mathrm{EC}, \mathrm{pH}$, organic matter, $\mathrm{N}, \mathrm{P}$ and $\mathrm{K}$ concentration as outlined by [17]. The soil samples were analyzed for soil particledistribution (texture) by Bouyoucos hydrometer method [18], $\mathrm{EC}$ and $\mathrm{pH}$ in 1:2 (soil:water) extracts by $\mathrm{EC}$ and $\mathrm{pH}$ meter, organic matter by Walkley-Black method [19], total $\mathrm{N}$ by Kjeldahl's method [20] and $\mathrm{P}$ and $\mathrm{K}$ by ammonium bicarbonate diethylene triamine penta-acetic acid (ABDTPA) extractable method [21]. Nitrogen in leaf tissue was determined by same method as in case of soil [20]. For P and K, the samples were acid digested in 1:5 $\mathrm{HClO}_{4}: \mathrm{HNO}_{3}$. Phosphorus in the digests was quantified by yellow colour (vanadomolybdo-phosphoric acid) method [22] by using absorption spectrophotometry, while $\mathrm{K}$ was directly determined by emission spectroscopy [23].

\section{Statistical analysis of the data}

The data of growth parameters, yield and yield contributing parameters and $\mathrm{N}, \mathrm{P}$ and $\mathrm{K}$ concentrations in cotton leaf tissue at maturity were subjected to analyses of variance using split plot design (major split - spentwash and sub-split as N-P rates). Data were statistically analyzed through Statistix 8.1 [24]. The means were compared using the Honest Significant Difference (HSD) only if the general treatment $F$ test was significant at probability of $\leq 0.05$ [25].

\section{Results}

\section{Spentwash characteristics}

The analytical data of spentwash samples indicated that $20 \%$ spentwash had a highest EC of $9.75 \mathrm{dS} \mathrm{m^{-1 }}$, followed by $15 \%$ spentwash $\left(8.85 \mathrm{dS} \mathrm{m}^{-1}\right), 10 \%\left(7.25 \mathrm{dS} \mathrm{m}^{-1}\right)$ and $5 \%$ which had a lowest EC of $4.15 \mathrm{dS}$ $\mathrm{m}^{-1}$ (Table 1). As for $\mathrm{pH}$ the values decreased with the increase in spentwash concentration (i.e. from $5 \%$ to $20 \%$ ). The respective $\mathrm{pH}$ values for $5,10,15$ and $20 \%$ spentwash concentration were: $8.20,8.12$, 7.91 and 7.85. The organic matter content was also higher in samples having higher spentwash concentration i.e. 5\% (0.25\%), $10 \%(0.71 \%), 15 \%(1.15 \%)$ and $20 \%$ $(1.30 \%)$. The total $\mathrm{N}$ of $176,389,725$ and $889 \mathrm{mg} \mathrm{L}^{-1}$, total $\mathrm{P}$ of 24.0, 52.2, 58.7 and $66.5 \mathrm{mg} \mathrm{L}^{-1}$ and total $\mathrm{K}$ of $900,2132,3686$ and $4345 \mathrm{mg} \mathrm{L}^{-1}$ was observed in 5, 10, 15 and $20 \%$ spentwash. The data showed that $\mathrm{N}, \mathrm{P}$, and $\mathrm{K}$ concentrations increased with increasing the spentwash concentration.

\section{Soil properties}

The soil of experimental site was silty clay loam in texture, consisting $20 \%$ of sand, $42.5 \%$ of silt and $37.5 \%$ of clay at surface and $18 \%$ sand, $43 \%$ silt and $39 \%$ clay at sub-surface with EC value of $0.7 \mathrm{dS} \mathrm{m}^{-1}$ and $\mathrm{pH}$ of 7.15 and 7.51 at respective soil depths (i.e. 0-15 and $15-30 \mathrm{~cm}$ ). The organic matter content of the soil was $0.81 \%$ and $0.65 \%$, Kjeldahl's $\mathrm{N}$ of $0.045 \%$ and $0.032 \%$, ABDTPA extractable P of 1.25 and $1.0 \mathrm{mg} \mathrm{kg}^{-}$ ${ }^{1}$ and $\mathrm{K}$ concentration of 80 and $70 \mathrm{mg} \mathrm{kg}^{-1}$ correspondingly at surface and subsurface (Table 2).

Effect of spentwash and chemical fertilizer (N-P) on growth, yield and leaf tissue $\mathrm{N}, \mathrm{P}$ and $\mathrm{K}$

The data (Table 3) showed that the foliar application of spentwash concentrations $(0$, $5,10,15$ and $20 \%), \mathrm{N}-\mathrm{P}$ rates $\left(0,1 / 3^{\text {rd }}, 2 / 3^{\text {rd }}\right.$ and full) and the interaction of both chemical fertilizer and spentwash significantly $(p<0.01)$ influenced the 
growth parameters (i.e. plant height, number of leaves and sympodial branches plant $^{-1}$, yield and yield contributing parameters (i.e. number of squares and bolls plant $^{-1}$ and seed cotton yield ha $^{-1}$ ) and leaf tissue nutrients $(\mathrm{N}, \mathrm{P}$ and $\mathrm{K})$ concentration in cotton. All the growth parameters, yield and yield contributing parameters and nutrient concentration increased with increasing the spentwash concentration from $0 \%$ to $20 \%$ or the N-P rates from 0 to full, except in case of $\mathrm{K}$, where the increase in N-P rates did not have a significant effect.

\section{Growth parameters}

The interaction of $20 \%$ spentwash spray and full N-P rate gave tallest plants $(130.77 \mathrm{~cm})$, maximum number of leaves (25.13) and sympodia (20.12) plant $^{-1}$. While, shortest plants $(103.20 \mathrm{~cm})$, minimum number of leaves (16.24) and sympodia (11.31) plant $^{-1}$ were observed under control (0 spentwash and $0 \mathrm{~N}-\mathrm{P})$. This resulted in $26.71 \%$ increase in plant height, $54.74 \%$ in number of leaves and $77.89 \%$ in sympodia over control. Increasing the spentwash concentration correspondingly from $15 \%$ to $20 \%$ integrated with $2 / 3^{\text {rd }}$ or full N-P rate did not have any significant effect on plant height $(130.17,130.37,130.53$ and 130.77 $\mathrm{cm})$, number of leaves $(25.05,25.08,25.11$ and 25.13) plant $^{-1}$ and sympodia (20.07, 20.09, 20.11 and 20.12) plant $^{-1}$ as given under (Fig. 1).

\section{Yield and yield contributing parameters}

The highest number of squares (27.70), bolls (40.24) plant $^{-1}$ and seed cotton yield (4025 kg) $\mathrm{ha}^{-1}$ were observed at $20 \%$ spentwash spray integrated with full N-P rate. The lowest number of squares (18.60) and bolls (20.66) plant $^{-1}$ and seed cotton yield $(2067 \mathrm{~kg}) \mathrm{ha}^{-1}$ was recorded under Table 1. Characteristics of spentwash concen control. Resultantly, there was $48.92 \%$ increase in number of squares, $94.77 \%$ in number of bolls and $94.73 \%$ in seed cotton yield at $20 \%$ spentwash and full N-P fertilizer over no spentwash and no N-P. The data in (Fig 2) depicted statistically similar number of squares (27.55) plant $^{-1}$, bolls (40.18) plant $^{-1}$ and seed cotton yield (4018 kg) ha ${ }^{-1}$ when N-P rate was reduced from full to $2 / 3^{\text {rd }}$ at $20 \%$ spentwash concentration. Likewise, number of squares (27.48 and 27.35) plant $^{-1}$, bolls (40.23 and 40.15) plant $^{-1}$ and seed cotton yield (4023 and $4016 \mathrm{~kg}$ ) ha ${ }^{-1}$ recorded, correspondingly at $15 \%$ spentwash integrated with full and $2 / 3^{\text {rd }}$ N-P were also at par with $20 \%$ spentwash at full and $2 / 3^{\text {rd }} \mathrm{N}-\mathrm{P}$ rates (Fig. 2).

\section{Leaf tissue nutrients ( $N, P$ and $K$ )}

Maximum N (3.40\%) and $\mathrm{P}(0.2 \%)$ concentration in leaf tissue (Fig. 3) was observed at full N-P rate integrated with $20 \%$ spentwash and minimum N (2.19\%) and $\mathrm{P}(0.09 \%)$ at control, which led to $55.25 \%$ increase in $\mathrm{N}$ and $122 \%$ in $\mathrm{P}$ over control. The treatments receiving $20 \%$ or $15 \%$ spentwash and full or $2 / 3^{\text {rd }}$ N-P had correspondingly similar leaf tissue $\mathrm{N}$ $(3.40 \%, 3.38 \%, 3.37 \%$ and $3.35 \%)$ and $\mathrm{P}$ concentration $(0.2 \%, 0.19 \%, 0.19 \%$ and $0.19 \%$ ) as in case of growth and yield parameters. In case of $\mathrm{K}$ in leaf tissue, the maximum value $(2.83 \%)$ was observed at $20 \%$ spentwash spray with $2 / 3^{\text {rd }} \mathrm{N}-\mathrm{P}$ and minimum (1.47\%) under control, headed to $92.5 \%$ increase in $\mathrm{K}$ concentration against control. The interaction data further showed that the spray of $20 \%$ spentwash alone $(2.79 \%)$, or integrated with each of three $\mathrm{N}$ $\mathrm{P}$ rates i.e. $1 / 3^{\text {rd }}(2.81 \%), 2 / 3^{\text {rd }}(2.83 \%)$ and full $(2.81 \%)$ did not significantly increase $\mathrm{K}$ concentration.

\begin{tabular}{|c|c|c|c|c|}
\hline \multirow{2}{*}{ Parameters } & \multicolumn{4}{|c|}{ Spentwash concentrations $(\%)$} \\
\hline & 5 & 10 & 15 & 20 \\
\hline$E C\left(d S m^{-1}\right)$ & 4.15 & 7.25 & 8.85 & 9.75 \\
\hline pH & 8.20 & 8.12 & 7.91 & 7.85 \\
\hline Organic matter (\%) & 0.25 & 0.71 & 1.15 & 1.30 \\
\hline Total N $\left(\mathrm{mg} \mathrm{L}^{-1}\right)$ & 176 & 389 & 725 & 889 \\
\hline Total $\mathbf{P}\left(\mathrm{mg} \mathrm{L}^{-1}\right)$ & 24.0 & 52.2 & 58.7 & 66.5 \\
\hline Total K $\left(\mathrm{mg} \mathrm{L}^{-1}\right)$ & 900 & 2132 & 3686 & 4345 \\
\hline
\end{tabular}


Table 2. Properties of experimental soil

\begin{tabular}{|c|c|c|}
\hline \multirow{2}{*}{ Soil Property } & \multicolumn{2}{|c|}{ Soil depth (cm) } \\
\hline & $0-15$ & 15-30 \\
\hline Particle distribution (\%) Sand & 20 & 18 \\
\hline Silt & 42.5 & 43 \\
\hline Clay & 37.5 & 39 \\
\hline Textural class & silty clay loam & silty clay loam \\
\hline EC in $1: 2$ soil-water extract $\left(\mathrm{dS} \mathrm{m}^{-1}\right)$ & 0.7 & 0.7 \\
\hline pH in 1:2 soil-water extract & 7.15 & 7.51 \\
\hline Organic matter $(\%)$ & 0.91 & 0.65 \\
\hline Kjeldahl's N (\%) & 0.045 & 0.032 \\
\hline AB-DTPA P (mg kg-1 soil) & 1.25 & 1.0 \\
\hline AB-DTPA K (mg kg-1 soil) & 80 & 70 \\
\hline
\end{tabular}

Table 3. F values and significance from analysis of variance for various growth parameters, yield and yield contributing parameters and leaf tissue $N, P$ and $K$ as affected by different spentwash concentrations and $\mathrm{N}$-P fertilizer rates

\begin{tabular}{|c|c|c|c|}
\hline Parameters & $\begin{array}{c}\text { Spentwash } \\
\text { concentrations }(\mathrm{SW})\end{array}$ & N-P rates & SW $\times$ N-P \\
\hline Plant height $(\mathrm{cm})$ & $9299 * *$ & $20061 * *$ & $216 * *$ \\
\hline Number of leaves plant ${ }^{-1}$ & $3066^{* *}$ & $12777 * *$ & $182 * *$ \\
\hline Number of sympodial branches plant ${ }^{-1}$ & $20730 * *$ & $21514 * *$ & $294 * *$ \\
\hline Number of squares plant ${ }^{-1}$ & $664 * *$ & $562 * *$ & $17.4 * *$ \\
\hline Number of bolls plant ${ }^{-1}$ & $22116^{* *}$ & $33846^{* *}$ & $393 * *$ \\
\hline Seed cotton yield $(\mathrm{kg}) \mathrm{ha}^{-1}$ & $21920 * *$ & $36154 * *$ & $419 * *$ \\
\hline $\mathbf{N}(\%)$ & $1388 * *$ & $1978 * *$ & $54.4 * *$ \\
\hline $\mathbf{P}(\%)$ & $951 * *$ & $1872 * *$ & $176^{* *}$ \\
\hline $\mathbf{K}(\%)$ & $1112 * *$ & $422 * *$ & $38.8^{* *}$ \\
\hline
\end{tabular}

NS - non significant; * and ** - significant at 0.05 and 0.01 probability level according to Honest Significant Difference (HSD) test
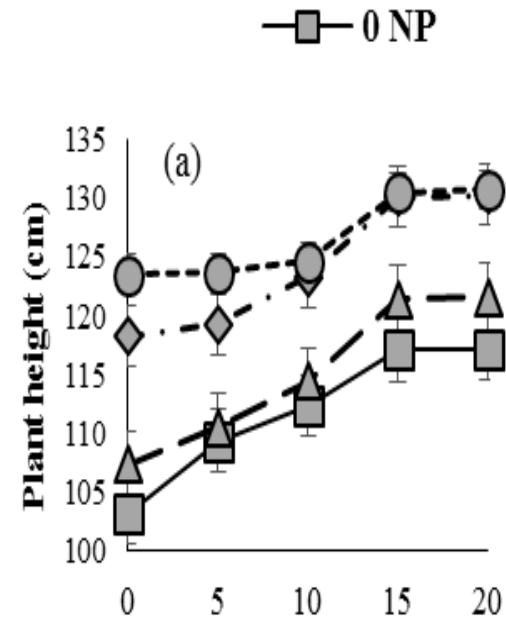

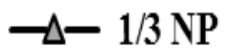

$-\diamond 2 / 3 N P$

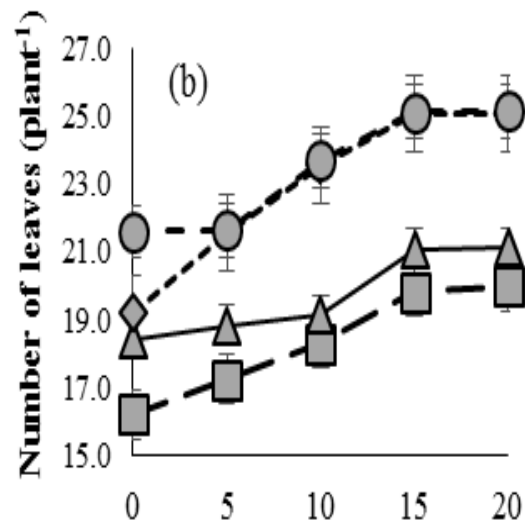

Spentwash concentrations (\%)

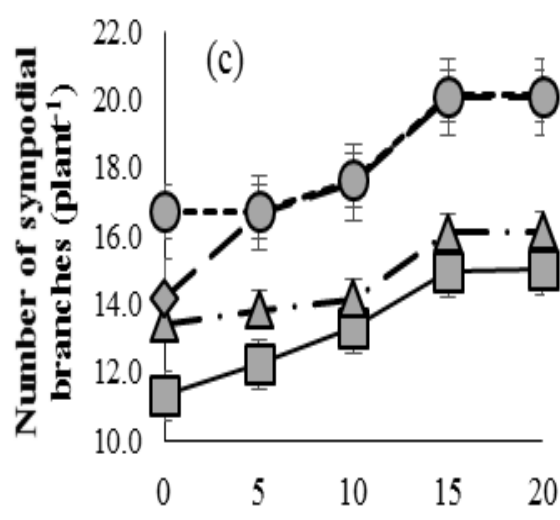

20

1. Effect of spentwash concentrations, N-P rates and their interaction on growt parameters. a Plant height. b Number of leaves plant ${ }^{-1}$. $c$ Number of sympodia plant ${ }^{-1}$ 

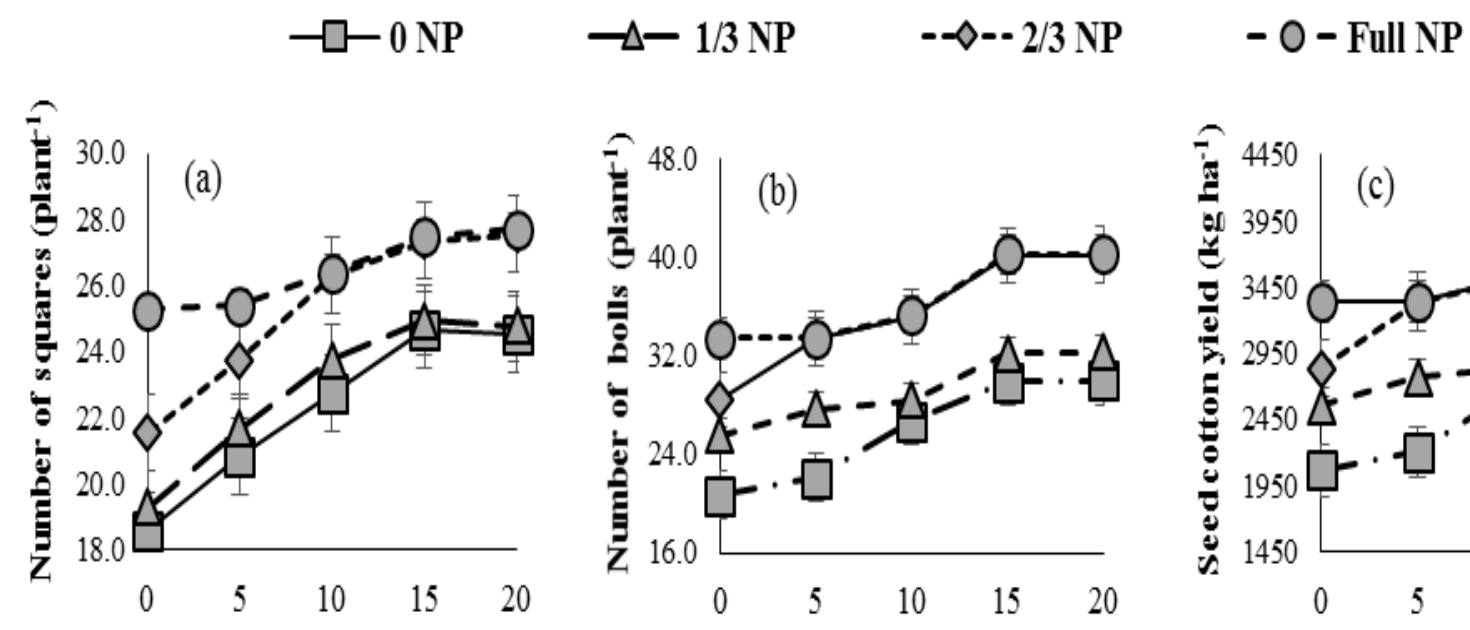

Spentwash concentrations (\%)

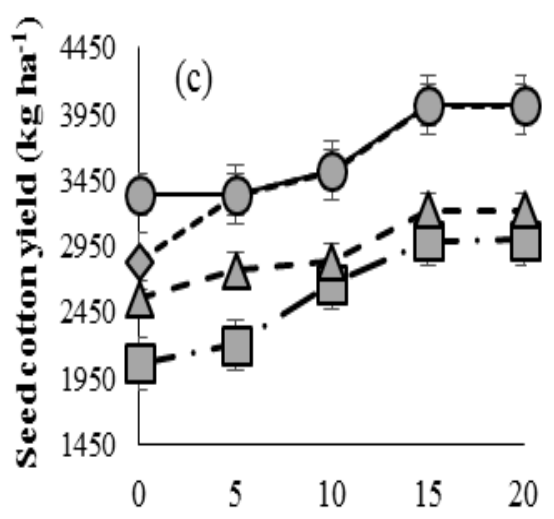

Figure 2. Effect of spentwash concentrations, N-P rates and their interaction on yield and yield contributing parameters. a Squares plant ${ }^{-1}$. b Bolls plant ${ }^{-1}$. c Seed cotton yield ha-1

$$
\rightarrow-0 N P \quad-\triangle-1 / 3 N P \quad \neg-2 / 3 N P \quad--0-- \text { Full NP }
$$
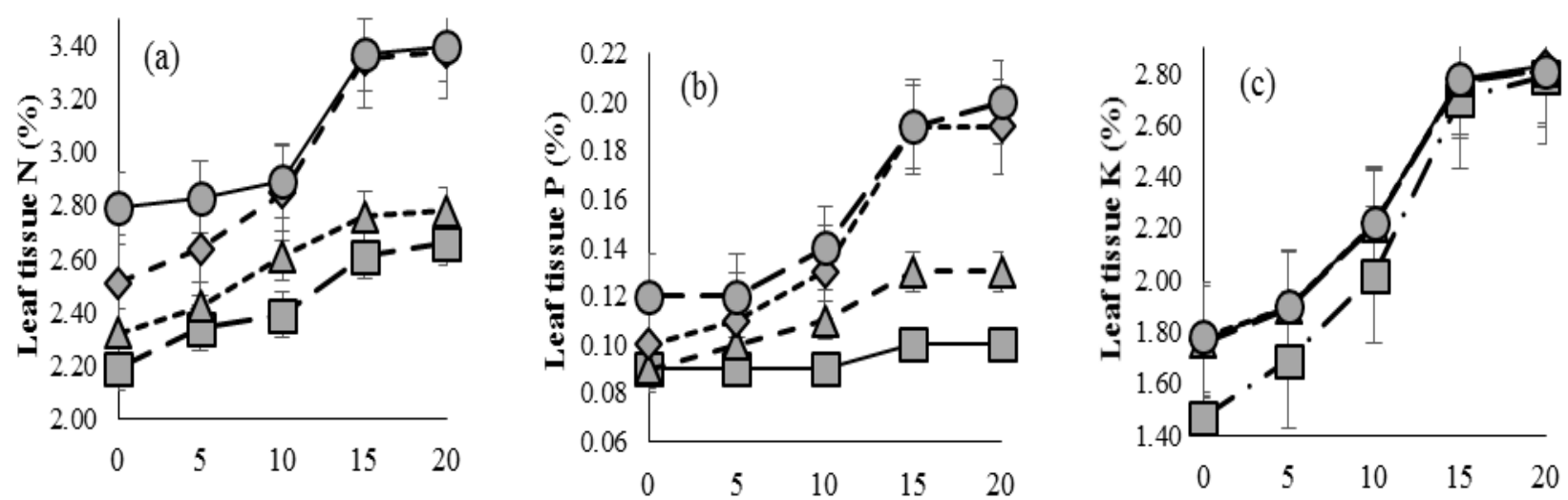

Spentwash concentrations (\%)

Figure 3. Effect of spentwash concentrations, N-P fertilizer rates and their interaction on $N, P$ and $K$ concentration in cotton leaf tissue. a Leaf tissue nitrogen. $b$ Leaf tissue phosphorus. $c$ Leaf tissue potassium

\section{Discussion}

One of the major problems faced by farmer community is the unaffordable prices of chemical fertilizers, which has resulted in low fertilizer inputs, not fulfilling the nutrient requirements as per crop recommendations [14]. Under this setup, expected yield targets are not achieved, unless a low-cost environment friendly nutrient addition, complimenting chemical fertilizers is available. In this study, we used sugar-industry based nutrient rich waste "spentwash" as a foliar spray in conjunction with chemical fertilizers. Past studies of soil- 
application spentwash have already highlighted its drawback of increasing the salt content [13]. The results of this study demonstrated a positive outcome in growth and yield of cotton by foliar spray of spentwash with N-P fertilizers. All the growth (plant height, number of leaves and sympodia), yield contributing parameters (squares and bolls), seed cotton yield and nutrient concentration $(\mathrm{N}, \mathrm{P}$ and $\mathrm{K})$ in leaf tissue increased with the increase in spentwash $(0,5$, $10,15,20 \%)$, chemical fertilizer rates $\left(0,1 / 3^{\text {rd }}\right.$, $23^{\text {rd }}$ and full) and the combination of the two (20\% spentwash and full N-P). [14] also reported significant increase in growth and yield of tomato at recommended rate of fertilizer and $20 \%$ spentwash spray. Our results also indicated $20 \%$ spentwash concentration as a cutoff point for cotton crop. As the concentration of spentwash increases, the colour intensity and the nutrient contents of this liquid also increase, which decrease the chlorophyll content, and slowing down the process of photosynthesis [26]. Analysis of the fertilizer treatments alone showed that varying the rate of N-P from $1 / 3^{\text {rd }}$ to full did not influence the $\mathrm{K}$ contents. Cotton being highly sensitive to $\mathrm{K}$ has responded well to $\mathrm{K}$ additions through chemical fertilizers [10, 27]. Here, this is obvious, as no $\mathrm{K}$ was applied in the form of chemical fertilizer. The $\mathrm{K}$ increase was only prominent when spentwash was applied alone and is in line with the results given by [28].

The nutrient application practices and its quantities from chemical fertilizers vary among cotton growers, however, majority of the growers apply $2 / 3^{\text {rd }}\left(93-46 \mathrm{~kg} \mathrm{~N}^{-} \mathrm{P}_{2} \mathrm{O}_{5} \mathrm{ha}^{-1}\right)$ of the recommended N-P (or little more $\mathrm{N}$ ) with no $\mathrm{K}$ due to its cost-related issues. A comparison of seed cotton yield under similar (farmer's practice) rate of N-P fertilizer $\left(2 / 3^{\text {rd }}\right)$ with spentwash spray of $20 \%$ exhibited even more yield $(20 \%)$ than that achieved at full N-P. Increasing the N-P rate from $2 / 3^{\text {rd }}$ to full and spentwash concentration from $15 \%$ to $20 \%$ did not have any benefit in terms of growth and yield of cotton and would not be fruitful. This may be that $2 / 3^{\text {rd }}$ rate of N-P with $20 \%$ spentwash has already fulfilled the nutrient requirement of cotton and the results of this study are proof of this. Under same setup, plant height (5.5\%), number of leaves $(16.1 \%)$, sympodia $(20 \%)$, number of squares (9\%), and bolls (20\%) increased to relevant percentages to head the yield target. In case of leaf tissue nutrients, the interaction of $20 \%$ spentwash with $2 / 3^{\text {rd }} \mathrm{N}-\mathrm{P}$ increased $\mathrm{N}$ by $21 \%, \mathrm{P}$ by $58 \%$ and $\mathrm{K}$ by $59 \%$ over full N-P alone. Our results are in line with the work of [14] and further supported by [16].

\section{Conclusion}

Spray of 20\% spentwash on cotton leaves, either alone or with full N-P soil application increased the growth, yield parameters, seed cotton yield and $\mathrm{N}, \mathrm{P}$ and $\mathrm{K}$ concentration in leaf tissue, leading to increased seed cotton yield. A $2 / 3^{\text {rd }} \mathrm{N}$ $\mathrm{P}$ rate with $20 \%$ spentwash also gave similar outcome as that obtained at full N-P and substituted $33 \%$ of each $\mathrm{N}$ and $\mathrm{P}$ and $100 \%$ of $\mathrm{K}$, saving N, P and $\mathrm{K}$ fertilizer cost of (Rs. 18750 $\mathrm{ha}^{-1}$ ) and $20 \%$ increase in seed cotton yield ha ${ }^{-1}$ over full N-P fertilizer alone.

\section{Authors' contributions}

Conceived and designed the experiments: $M$ Memon, Performed the experiments: WH Shah, Analyzed the data: WH Shah \& M Memon, Contributed materials/ analysis/ tools: $\mathrm{M}$ Memon, Wrote the paper: M Memon \& WH Shah.

\section{References}

1. Pakistan Bureau of Statistics (2018-19). Pakistan Economic Survey, Economic Advisor Wing, Finance Division, Govt. Pakistan, Islamabad.

2. FAOSTAT (2016-17). Statistical Database. Food and Agricultural Organization (FAO). Available online, www.faostat.fao.org.

3. Ahmed AUH, Ali R, Zamir SI \& Mahmood $N$ (2009). Growth, yield and quality performance of cotton cultivar BH-160 (Gossypium hirsutum L.) as influenced by different plant spacing. J Anim Plant Sci 19: 189-192.

4. Munir MK, Tahir M, Saleem MF \& Yaseen $M$ (2015). Growth, yield and earliness response of cotton to row spacing and nitrogen management. J Anim Plant Sci 25(3): 729-738.

5. Sampathkumar T, Krishnasamy S, Ramesh S, Prabukumar G \& Gobi R (2006). Growth, nutrient uptake and seed cotton yield of summer cotton as influenced by drip, surface irrigation methods and mulching practices. Res J Agri Biol Sci 2(6): 420-422.

6. Saleem MF, Bilal MF, Awais M, Shahid MQ \& Anjum SA (2010). Effect of nitrogen on seed cotton yield and fiber qualities of cotton (Gossypium hirsutum L.) cultivars. $J$ Anim Plant Sci 20(1): 23-27. 
7. Sawan ZM, Mahmoud MH \& El-Guibali $\mathrm{AH}$ (2008). Influence of potassium fertilization and foliar application of zinc and $\mathrm{P}$ on growth, yield and fiber properties of Egyptian cotton (Gossypium barbadense L.). J Plant Ecol 1: 259-270.

8. Zhao D, Oosterhuis DM \& Bednarz CW (2001). Influence of potassium deficiency on photosynthesis, chlorophyll content, and chloroplast ultrastructure of cotton plants. Photosynthetica 39(1): 103-109.

9. Wang L \& Chen F (2012). Genotypic variation of potassium uptake and use efficiency in cotton (Gossypium hirsutum L). J Plant Nutr Soil Sci 175(2): 303-308.

10. Rosolem CA \& Mikkelsen DS (1991). Potassium absorption and partitioning in cotton as affected by periods of potassium deficiency. J Plant Nutr 14(9): 1001-1016.

11. Silvertooth JC (2007). Cotton (Gossypium spp.). In: World Fertilizer Use Manual. International Fertilizer Industry Association (IFA). http://www.fertilizer.org/ifa/publicat/html/ pubman/ cotton.htm.

12. Kumar V \& Chopra AK (2011). Impact on physico-chemical characteristics of soil after irrigation with distillery effluent. Arch Appl Sci Res 3(4): 63-77.

13. Kaloi GM, Memon M, Memon KS, Ahmad S, Sheikh SA \& Jamro GM (2017). Effect of sugar industry spentwash (diluted) on the characteristics of soil and sugarcane (Saccharum officinarum L.) growth in the subtropical environment of Sindh, Pakistan. Environ Monit Assess 189: 127.

14. Savitha HR (2015). Studies on fortification of distillery spentwash for foliar application and its effect on soil properties, growth and yield of tomato. PhD thesis. Deptt. Of Soil Sci. \& Agri Chem, Univ of Agri Sci, Bengalure.

15. Ramana S, Biswas AK, Kundu S, Saha JK \& Yadava RBR (2000). Physiological response of soybean (Glycine $\max$ L.) to foliar application of distillery effluent. Ann Plant Soil Res 2: 1-6.

16. Babu RS, Saralabai VC, Muralidharan KS \& Vivekanandan M (1996). Foliar application of distillery spentwash as a liquid fertilizer for betterment of growth of Sorghum vulgare and Cajanus cajan. Appl Biochem Biotech 59: 87-91.
17. APHA, AWWA \& WEF (1998). Standard methods for examination of water and wastewater. $20^{\text {th }}$ Ed. DC: American Public Health Association; Washington.

18. Bouyoucos GH (1962). Hydrometer method improved for making particle-size analysis of soils. Agron J 54: 464-465.

19. Walkley A \& Black IA (1934). An examination of the method for determining soils organic matter and a proposed modification of the chromic acid titration method. Soil Sci 37: 2938.

20. Jackson ML (1958). Soil chemical analysis. Prentice-Hall, Inc., Englewood Cliffs; New Jersey, pp. 87-110.

21. Soltanpour PN \& Workman S (1979). Modification of the $\mathrm{NH}_{4} \mathrm{HCO}_{3}$-DTPA soil test to omit carbon black. Commun Soil Sci Plant Anal 10: 1411-1420.

22. Cottenie A (1980). Soil and plant testing as a basis of fertilizer recommendations. FAO Soils Bulletin, 38/2, FAO; Rome.

23. Knudsen D, Peterson GA \& Pratt PF (1982). Lithium, sodium and potassium. In: AL Page (Ed.). Methods of Soil Analysis, Part 2: Chemical and microbiological properties. American Society of Agronomy; Madison, WI (USA), pp. 225245.

24. Analytical Software (2005). Statistix 8.1 User's manual. Tallahassee, (FL): Analytical Software.

25. Gomez KA \& Gomez AA (1984). Statistical procedures for Agricultural Research, $2^{\text {nd }}$ Ed. John Wiley \& Sons; New York.

26. Rath P, Pradhan G \& Misra MK (2011). Effect of distillery spentwash (DSW) and fertilizer on growth and chlorophyll content of sugarcane (Saccharum officinarum L.) plant. Rec Res Sci Tech 3(4): 169-176.

27. Zia-ul-hassan, Kubar KA, Rajpar I, Shah AN, Tunio SD, Shah JA \& Mailto AA (2014). Evaluating potassium-useefficiency of five cotton genotypes of Pakistan. Pak J Bot 46(4): 1237-1242.

28. Krishnamurthy D (2010). Effect of fertigation with distillery spentwash on soil fertility, growth, yield and quality of banana (Musa paradisiaca L.). $\mathrm{PhD}$ thesis. Deptt of Agron, Univ of Agri Sci, Bengaluru. 